\title{
Commentary: Can we dramatically reduce the number of staged repairs?
}

\author{
Jean Bachet, MD, FEBTCS
}

$\overline{\text { From ADETEC }}$, Surgical Association for the Development and Improvement of Screening and Treatment Techniques for Cardiovascular Diseases, Suresnes, France.

Disclosures: Author has nothing to disclose with regard to commercial support.

Received for publication Sept 5, 2018; accepted for publication Sept 6, 2018; available ahead of print Oct 25, 2018.

Address for reprints: Jean Bachet, MD, FEBTCS, ADETEC, 1 Place Marcel Legras, 92150 Suresnes, France (E-mail: jean.bachet@yahoo.fr).

J Thorac Cardiovasc Surg 2019;157:2148-9

$0022-5223 / \$ 36.00$

Copyright $₫ 2018$ by The American Association for Thoracic Surgery

https://doi.org/10.1016/j.jtcvs.2018.09.016

The important experience of the Kobe group concerning 118 staged procedures performed in 82 patients with Marfan syndrome, published by Ikeno and colleagues ${ }^{1}$ in this issue of the Journal, is remarkable. The results have been outstanding in terms of operative mortality, neurologic accidents, and long-term survival, even though one may regret that no information was provided in detail concerning the possible immediate complications.

Ikeno and colleagues ${ }^{1}$ included in their study only the procedures performed in their department. But one may observe that 28 patients had previously undergone 32 operations, and that the 82 patients had actually undergone 150 surgical procedures. What Ikeno and colleagues ${ }^{1}$ classify as a first-, second- or third-stage operation was actually the second, third, or fourth one. This underlines the fact that the surgical teams and also, the patients, who generally are well informed about their condition, are aware that several late operations might be necessary in the future, especially if the first procedure has been performed for acute dissection.

Facing those dilemmas, a major question is raised: Is it possible to reduce the rates of reoperations? As largely alluded to in the article of Ikeno and colleagues, ${ }^{1}$ it seems that the answer may be positive.

During the last 2 or 3 decades, the analysis of spontaneous postoperative aortic evolution, the progress made in the indications and in the surgical and interventional techniques, and the resort to more efficacious medical treatments have indeed led to strategies of long-term stable procedures and normal life expectancy through extended and even total aortic replacements or repair. There is no doubt that in patients undergoing elective surgery with a dilated root larger than $45 \mathrm{~mm}$, this segment should be replaced. The current large development and use of the

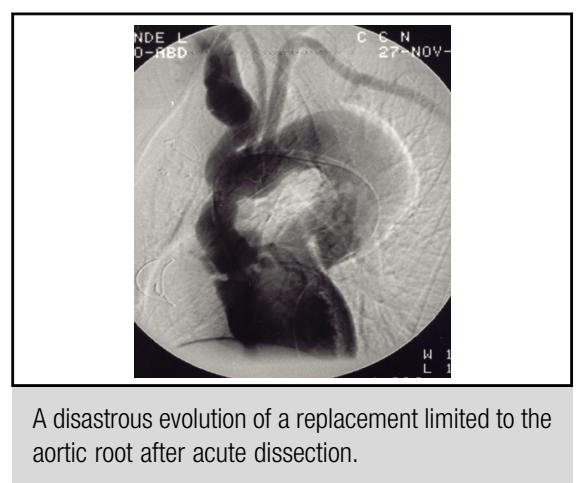

\section{Central Message}

In patients with Marfan syndrome, repeated operations are often required. Could stricter strategies in the surgical techniques dramatically reduce the rate of staged operations?

See Article page 2138 .

valve-sparing procedures allow safe and durable results with reduced risk. In those patients, it was also demonstrated several years ago that extending the replacement distally is not necessary, because the late evolution is most generally stable. . $^{2-4}$

It seems also largely demonstrated that in patients operated on for acute type A dissection, the replacement of the aortic root is mandatory but the replacement of the total arch is also of utmost importance. Replacements limited to the ascending aorta result almost systematically in a disastrous evolution. Ideally, this total arch replacement should be done with such techniques as cannulation of the supraaortic vessels, hypothermic circulatory arrest and selective antegrade cerebral perfusion, open distal anastomosis, and separate reimplantation of the supra-aortic vessels. This replacement should also be associated systematically with the elephant trunk technique to provide a safe and easy possibility of distal repair if needed in the future or even, as has been proposed for a few years, with the frozen elephant trunk technique to induce a false-lumen thrombosis in the descending aorta. ${ }^{5}$

When for any reason some replacement of the thoracoabdominal aorta is required, the most frequently observed complication is, in addition to the dreadful 
spinal cord injury, probably the aneurysmal dilatation of aortic patches used to reimplant the intercostal and visceral arteries. To prevent those complications, it seems appropriate either to reimplant the intercostal arteries through prosthetic conduits or perhaps to avoid any reimplantation of those arteries, in accordance with the collateral network concept, ${ }^{6,7}$ as well as reimplanting the visceral arteries separately, with available ready-made prostheses.

All those indications and techniques may seem rather stringent. Nevertheless, they may be the best way to limit the number of staged repairs, especially in patients with acute dissection. An increasing consensus about most of those techniques can be observed now, and one may hope that in the close future this will help in limiting to only 1 or 2 the number of late-stage procedures that are so worrisome for the surgical team and awfully frightening for the patients.

\section{References}

1. Ikeno Y, Yokawa K, Nakai H, Yamanaka K, Inoue T, Tanaka H, et al. Results of staged repair of aortic disease in patients with Marfan syndrome. J Thorac Cardiovasc Surg. 2019;157:2138-47.e2.

2. Tagusari O, Ogino H, Kobayashi J, Bando K, Minatoya K, Sasaki H, et al. Should the transverse aortic arch be replaced simultaneously with aortic root replacement for annuloaortic ectasia in Marfan syndrome? J Thorac Cardiovasc Surg. 2004; 127:1373-80.

3. Bachet J, Larrazet F, Goudot B, Dreyfus G, Folliguet T, Laborde F, et al. When should the aortic arch be replaced in Marfan patients? Ann Thorac Surg. 2007; 83:774-9.

4. Schoenhoff FS, Kadner A, Czerny M, Jungi S, Meszaros K, Schmidli J, et al Should aortic arch replacement be performed during initial surgery for aortic root aneurysm in patients with Marfan syndrome? Eur J Cardiothorac Surg. 2013;44:346-51; discussion 351.

5. Roselli EE, Idrees JJ, Lowry AM, Masabni K, Soltesz EG, Johnston DR, et al. Beyond the aortic root: staged open and endovascular repair of arch and descending aorta in patients with connective tissue disorders. Ann Thorac Surg. 2016;101:906-12.

6. Griepp RB, Griepp EB. Spinal cord perfusion and protection during descending thoracic and thoracoabdominal aortic surgery: the collateral network concept. Ann Thorac Surg. 2007;83:S865-9; discussion S890-2.

7. Etz CD, Homann TM, Plestis KA, Zhang N, Luehr M, Weisz DJ, et al. Spinal cord perfusion after extensive segmental artery sacrifice: can paraplegia be prevented? Eur J Cardiothorac Surg. 2007;31:643-8. 